\title{
Chill-induced changes in fatty acid composition of tonoplast vesicles from hypocotyls of Vigna unguiculata (L.) Walp.
}

\author{
Luciana M. N. de Oliveira, ${ }^{1,2}$, Alana C. de M. Sobreira', Fernando de P. Monteiro' ${ }^{1}$ \\ and Dirce F. de Melo ${ }^{1 *}$.
}

\author{
${ }^{1}$ Departamento de Bioquímica e Biologia Molecular. Universidade Federal do Ceará. Caixa Postal, 1065. \\ CEP-60.455-900. Fortaleza, Ceará, Brasil. \\ ${ }^{2}$ Unidade Acadêmica de Garanhuns. Universidade Federal Rural de Pernambuco. Garanhuns, Pernambuco, Brasil. \\ *Corresponding author: dirmelo@ufc.br \\ Received: 02 February 2010; Accepted: 31 May 2010.
}

\section{ABSTRACT}

The present study was undertaken to investigate the changes induced by chilling on fatty acid composition of tonoplast vesicles from hypocotyls of Vigna unguiculata (L.) Walp. The 7 day-old control seedlings were grown at $25^{\circ} \mathrm{C}$ while treated seedlings were submitted to low temperatures $\left(10^{\circ} \mathrm{C}\right.$ and $\left.4^{\circ} \mathrm{C}\right)$ for 4 days after 3 days germination. The chilling stress resulted in a differential inhibition of plant growth at $10^{\circ} \mathrm{C}$ and $4^{\circ} \mathrm{C}$. Following chilling at $10^{\circ} \mathrm{C}$ and $4^{\circ} \mathrm{C}$, the rate of unsaturated to saturated fatty acids increased under chilling stress. Our results suggest that the increase of unsaturated fatty acids content as well as the higher rate unsaturated/saturate fatty acids might be used by $V$. unguiculata plants as an adaptation mechanism likely to maintain the vacuolar membrane fluidity under low temperatures.

Key words: chilling, cowpea, lipid, fatty acids, membrane, vacuole.

\section{RESUMO}

0 presente trabalho analisa as mudanças na composição de ácidos graxos de vesículas de tonoplato de hipocótilos de Vigna unguiculata (L.) Walp induzida por estresse causado por baixas temperaturas. Plântulas em condição controle desenvolveram-se por 7 dias à temperatura de $25^{\circ} \mathrm{C}$ e as plântulas tratadas foram submetidas a 10 ou $4^{\circ} \mathrm{C}$ por 4 dias, 3 dias após a germinação a $25^{\circ} \mathrm{C}$. 0 frio $\left(10\right.$ ou $\left.4^{\circ} \mathrm{C}\right)$ induziu um efeito inibitório no desenvolvimento das plântulas e esse efeito foi mais pronunciado a $4^{\circ} \mathrm{C}$. Além disso, o grau de insaturação dos ácidos graxos nas vesículas de tonoplasto aumentou sob 0 efeito do frio, o que pode indicar um aumento da permeabilidade das vesículas da membrana vacuolar. Nossos resultados sugerem que plantas de $V$. unguiculata aumentaram o seu conteúdo de ácidos graxos insaturados bem como a razão entre ácidos graxos insaturados/saturados, como mecanismo de adaptação ao frio numa tentativa de manter a fluidez da membrana vacuolar.

Palavras-chave: ácidos graxos, caupi, frio, lipídios, membrana, vacúolo 


\section{INTRODUCTION}

Low temperature is an important environmental factor that influences the growth, development, survival and distribution of plants (Levitt, 1980; Renaut et al., 2004; Lee et al., 2009). Most plants from temperate regions can cold-acclimate in nonfreezing temperatures (Guy, 1990). However, plants adapted to tropical climates are usually more sensitive to chilling and this sensibility could vary widely (Yoshida et al. 1993; Nogueira et al., 2003). One of the most pronounced effect of chilling in plants is the alterations in the cellular membranes (Kasamo et al., 2000; Larkindale and Huang, 2004; Lee et al., 2005). Lipids are recognized as major chemical component of biological membranes playing an important role in cellular activities throughout the permeability, fluidity, and membrane-bound enzyme activities (Quinn and Williams, 1978; Yoshida and Uemura, 1986). Indeed, these diverse functions depend of the membrane stability and its fatty acids composition. Few reports address the effect of chilling on membranes from organelles such as vacuolar membrane (tonoplast) (Kasamo et al. 2000; Yoshida et al. 1993). In this context, we propose to investigate chill-induced changes on the fatty acid composition of tonoplast vesicles isolated from hypocotyls and their effect on development of Vigna unguiculata (L.) Walp.

\section{MATERIAL AND METHODS}

Seeds of V. unguiculata (L.) Walp cultivar Vita 3 (Seeds Bank of Universidade Federal do Ceará) were previously imbibed in distilled water for $1 \mathrm{~h}$ and germinated in filter paper, in darkness at $25^{\circ} \mathrm{C}$ (control). Three-day-old-seedlings were exposed to $10^{\circ} \mathrm{C}$ and $4^{\circ} \mathrm{C}$ for four days. For evaluation the growth effect by chilling the three-day-old-seedlings were submitted also for 3 days at $10^{\circ} \mathrm{C}$ and placed back at $25^{\circ} \mathrm{C}$ for 1 day. The fresh weight of different parts of seedlings was measured using analytic balance. At the end of treatment (7 days) the hypocotyls from plants were harvested for the isolation of tonoplast-enriched vesicles (Mariaux et al. 1997 modified by Otoch et al. 2001).

The total lipids from tonoplast vesicles were extracted in chloroform:methanol: water (1:1:1) according Bligh and Dyer (1959) with some modifications (Monteiro de Paula et al., 1990). The fatty acids were quantified by gas liquid chromatography, as previously described (Monteiro de Paula et al., 1990). The lipid bands were scraped off, saponified and fatty acids were methylated with boron trifluoride. Heptadecanoic acid (C17:0) was used as an internal standard for gas chromatography analysis.

\section{RESULTS AND DISCUSSION}

The exposure of 7-day-old seedlings of $V$. unguiculata (L.) Walp to chilling stress $\left(10\right.$ and $\left.4^{\circ} \mathrm{C}\right)$ resulted in drastic impairment of growth (Table 1). It was observed that inhibition of seedling development was proportionally affected by low temperatures. The roots fresh weight was inhibited by chilling c.a $34 \%$ at $10^{\circ} \mathrm{C}$ and $45 \%$ at $4^{\circ} \mathrm{C}$ but this inhibition was overcame when seedlings returned to control temperature $\left(25^{\circ} \mathrm{C}\right)$, resulting in growth recover. Hypocotyls were also inhibited by chilling with greater inhibition observed at $4^{\circ} \mathrm{C}$ ( $\sim 62 \%)$, twice than that at $10^{\circ} \mathrm{C}(36.4 \%)$. The epycotyl was revealed as the most sensitive organ to chilling, showing a decrease in fresh weight by $40 \%$ at $10^{\circ} \mathrm{C}$ and $67 \%$ at $4^{\circ} \mathrm{C}$. It should be noted that when seedlings were transferred back to ambient conditions $\left(25^{\circ} \mathrm{C}\right)$, the damage promoted by chilling to epocotyls was nearly irreversible, contrary to hypocotyls (Table 1).

Table 1. The effect of chilling on growth development of Vigna unguiculata seedlings. Three-day-old-seedlings were transferred to 10 and $4^{\circ} \mathrm{C}$ during $4 \mathrm{~d}$, the three-day-old-seedlings were submitted also to $10^{\circ} \mathrm{C}$ for 3 days and placed back at $25^{\circ} \mathrm{C}$ for 1 day. The data represent the average of 90 seedlings for each condition obtained in three independent experiments.

\begin{tabular}{cccc}
\hline Treatment & Root $\mathbf{( g )}$ & $\begin{array}{c}\text { Hypocotyl } \\
(\mathbf{g})\end{array}$ & $\begin{array}{c}\text { Epycotyl } \\
(\mathbf{g})\end{array}$ \\
\hline $25^{\circ} \mathrm{C}(7 \mathrm{~d}$, control) & 0.298 & 1.1 & 0.079 \\
$10^{\circ} \mathrm{C}(4 \mathrm{~d})$ & 0.194 & 0.7 & 0.0473 \\
$4^{\circ} \mathrm{C}(4 \mathrm{~d})$ & 0.162 & 0.42 & 0.0262 \\
$10^{\circ} \mathrm{C}(3 \mathrm{~d})+$ return to $25^{\circ} \mathrm{C}(1 \mathrm{~d})$ & 0.217 & 0.967 & 0.0316 \\
\hline
\end{tabular}

The total fatty acid composition of tonoplast vesicles from $V$. unguiculata seedlings in control $\left(25^{\circ} \mathrm{C}\right)$ as well as in chill stress conditions $\left(4\right.$ and $10^{\circ} \mathrm{C}$ ) was evaluated and revealed the presence of palmitic (16:0), linoleic (18:2), linolenic (18:3) and stearic acid (18:0) (Table 2). In control condition, the prevailing fatty acid was palmitic while stearic 
was less representative. The content of saturated fatty acids were decreased by $20 \%$ for palmitic acid at both low temperatures and 30 and $44 \%$ for estearic acid at $10^{\circ} \mathrm{C}$ and $4^{\circ} \mathrm{C}$, respectively, than compared to control. Notably, in response to chilling the amount of linoleic acid (18:2) increased $25 \%$ at $10^{\circ} \mathrm{C}$ and $7 \%$ at $4{ }^{\circ} \mathrm{C}$ while the amount of linolenic acid (18:3) were augmented by $27 \%$ and $33 \%$ at $4^{\circ} \mathrm{C}$ and $10^{\circ} \mathrm{C}$, respectively.

Chilling is an important environmental stress that interferes with the productivity of many important crops. Vigna unguiculata (L.) Walp is a tropical culture acclimated to warm temperatures, therefore it is considered a chilling sensitive crop. In fact, the growth development of $V$. unguiculata seedlings submitted to low temperatures was inhibited at $4^{\circ} \mathrm{C}$ to a more extent than $10^{\circ} \mathrm{C}$. Our results are in accordance to those obtained by Darley et al. (1995) with mung bean seedlings (Vigna radiata (L.) Wilczek) that revealed that seedlings exposure at $4^{\circ} \mathrm{C}$ effectively prevented the growth development. Indeed, this effect was not irreversible once growth recover was observed when seedlings exposed to chilling $\left(10^{\circ} \mathrm{C}\right)$ were transferred back to ambient warm temperatures (Table 1).

Cold stress triggers drastic changes in plant physiology. The structural and functional stability of membrane is crucial for plant adaptation to temperature stresses, and damage in membrane structure can led to changes in membrane semi permeability as well as changes in some membrane-localized enzymes (Kratsch and Wise, 2000; Lee and Lee, 2000; Vani et al., 2001; Zhang et al., 2001). Therefore we attempted to evaluate tonoplast fatty acid composition from hypocotyls of $V$. unguiculata seedlings under chilling conditions. Our results showed that in control seedlings, the prevailing fatty acid was a palmitic acid (Table 1). In the same way, Yoshida and Uemura (1986) showed that both plasma membrane and tonoplast from mung bean under control condition contain high levels of palmitic acid which result in low degree of unsaturation. The amount of unsaturated fatty acids $(18: 2,18: 3)$ from $V$. unguiculata under chilling $\left(10^{\circ} \mathrm{C}\right.$ and $\left.4^{\circ} \mathrm{C}\right)$ was higher than in the control condition $\left(25^{\circ} \mathrm{C}\right)$ (Table 2). The enhancement of unsaturated to saturated fatty acids rate in our results can be explained as the vesicles membrane permeability augmentation at low temperatures.
Table 2. Fatty acid composition of tonoplast hypocotyls. The experimental results shown are the average of triplicate measurements. Standard errors of analysis were estimated to be within $3 \%$.

\begin{tabular}{cccc}
\hline \multirow{2}{*}{ Fatty acid } & \multicolumn{3}{c}{$(\%)$} \\
\cline { 2 - 4 } & $25^{\circ} \mathrm{C}$ (control) & $10^{\circ} \mathrm{C}$ & $4^{\circ} \mathrm{C}$ \\
\hline $16: 0$ (palmitic acid) & 41.4 & 33.2 & 33 \\
18:0 (stearic acid) & 7 & 4.9 & 3.9 \\
18:2 (linoleic acid) & 27.6 & 34.5 & 30 \\
18:3 (linolenic acid) & 24 & 27.4 & 33 \\
\hline
\end{tabular}

The most common changes in fatty acid composition at low temperatures include an enhancement of unsaturated fatty acids amounts, increased ratio of short chain to long chain fatty acids, and/or alterations in branched chain fatty acid content (Suutari and Laakso, 1994). According to Neidleman (1987) this alteration in fatty acid composition of biological membranes as a common response to chilling is responsible for the maintenance of appropriate membrane fluidity. Our results confirm this idea and demonstrate that cowpea seedlings alter the lipid composition as a part of global adaptive response to chilling stress. These changes could reflect an attempt to maintenance of vacuolar membrane fluidity through the higher unsaturated fatty acid. The vacuole is an organelle that plays important roles in plant physiology, such as storage of metabolites, toxic ions, proteins etc, and is actively involved in membrane transport (Taiz, 1992; Martinoia et al., 2007). The importance of lipids in the membrane structure is well known as well as in modulation of membrane- bound enzymes (Zhang et al., 2006). Also, the lipid environment can play a role in regulation of the vacuolar proton V-ATPase (tonoplast proton pump) (Kasamo et al., 2000; unpublished results). This enzyme is considered as stress marker being responsive to many environmental stresses (Luttge et al., 2001), thus it is likely that the changes in lipid composition detected in present study can be responsible for changes in membrane transport, aside the stability of tonoplast. Future investigations are needed to establish a correlation between the alterations in lipids species and proton pumping mediated by V-ATPase.

Acknowledgments: This work was supported by fellowshipsfrom CNPq (Conselho Nacional de Desenvolvimento Científico e Tecnológico) and CAPES (Coordenação de Aperfeiçoamento de Pessoal de Nível Superior). 


\section{REFERENCES}

Bligh EG, Dyer WJ (1959) A rapid method of total lipid extraction and purification. Can. J. Biochem. Physiol. 37: 911-917.

Darley C P, Davies, J M and Sanders D (1995) Chill-induced changes in the activity and abundance of the vacuolar proton-pumping pyrophosphatase from mung bean hypocotyls. Plant Physiol. 109: 659-665.

Guy C L (1990) Cold acclimation and freezen stress tolerance: role of protein metabolism. Annu. Rev. Plant Physiol. Plant Mol. Biol. 41, 187-223.

Kasamo K, Yamaguchi M and Nakamura Y (2000) Mechanism of the chillinginduced decrease in proton pumping across the tonoplast of rice cells. Plant Cell Physiol. 33: 609-616.

Kasamo, K and Noushi, I (1987) The Role of Phospholipids in Plasma Membrane ATPase Activity in Vigna radiata L. (Mung Bean) Roots and Hypocotyls. Plant Physiol. 83:323-328.

Larkindale J, Huang B (2004) Changes of lipid composition and saturation level in leaves and roots for heat-stressed and heat acclimated creeping bentgrass (Agrostis stolonifera), Environ Exp Bot 51: 57-67.

Lee DG, Ahsan N, Lee SH, Lee JJ, Bahk JD, Kang KY, Lee BH (2009) Chilling stress-induced proteomic changes in rice roots. J. Plant Physiology 166:1-11.

Lee DH, Lee CB. (2000) Chilling stress-induced changes of antioxidant enzymes in the leaves of cucumber: in gel enzyme activity assays, Plant Sci. 15975-85.

Lee SH, Chung GC, Steudle E (2005) Gating of aquaporins by low temperature in roots of chilling sensitive cucumber and chilling-tolerant figleaf gourd. J Exp Bot 56: 985-994.

Levitt J (1980) Responses of Plants to Environmental Stresses (Academic, New York), 2nd Ed., Vol. 1.

Luttge U; Fischer-Schliebs E; Ratajczak R. (2001) The H+-pumping V-ATPase of higher plants: a versatile eco-enzyme in response to environmental stress. Cell. Biol. Mol. Lett. 6:356-361

Mariaux, J.-B., Fischer-Schliebs, E., Luttge, U. and Ratajczak, R. (1997) Dynamics of activity and structure of the tonoplast vacuolar-type $\mathrm{H}+$-ATPase in plants with different CAM expression and in a C3 plant under salt stress. Protoplasma 196: 181-189

Martinoia E, Maeshima M, Neuhaus H E (2007) Vacuolar transporters and their essential role in plant metabolism. J Exp Bot 58:83-102.
Monteiro de Paula, F. T, Pham Ti. A. ; J, V. S. ; M, J. A.; C, D. ; P, M. . Effects of Water Stress on the Molecular Species Composition of Polar Lipids from Vigna unguiculata (L.) Walp Leaves. Plant Science, 66: 185-193, 1990.

Neidleman SL (1987) Effects of temperature on lipid unsaturation. Biotech Genet Eng Rev 5:245-268.

Nogueira TS, De Rosa VE, Menossi M, Ulian EC, Arruda P (2003) RNA expression profiles and data mining of sugarcane response to low temperature. Plant Physiol 132: 1811-1824.

Otoch M.L.O.; Sobreira A.C.M.; Aragão M.E.F.; Orellano E.G.; Silva lima M.G.; Fernandes de Melo D. Salt modulation of vacuolar $\mathrm{H}^{+}$-ATPase and $\mathrm{H}^{+}$Pyrophosphatase activities in Vigna unguiculata. J. Plant Physiol. v. 158, p. 545-551, 2001.

Quinn, P.J. Williams, W.P. (1978) Plant lipids and their role in membrane function. Progress in Biophysics and Molecular Biology. 34, 109-173.

Renaut J, Lutts S, Hoffmann L, Hausman JF (2004) Responses of poplar to chilling temperature: proteomics and physiological aspects. Plant Biol 6 : $81-90$.

Suutari M and Laakso S. (1994) Microbial fatty acids and thermal adaptation. Crit. Rev. Microbiol. 20 285-328.

Taiz L (1992) The plant vacuole. J. Exp. Biol. 172: 113-122.

Vani B, Saradhi P, Mohanty P. (2001) Alteration in chloroplast structure and thylakoid membrane composition due to in vivo heat treatment of rice seedlings: correlation with the functional changes, J. Plant Physiol. 158 583-592.

Yoshida S, Uemura M (1986) Lipid composition of plasma membranes and tonoplasts isolated from etiolated seedlings of mung bean (Vigna radiata L.). Plant Physiol82: 807-812.

Yoshida, S., Hattanda, Y. and Suyama, T (1993) Variations in the chilling sensitivity of suspension-cultured cells of mung bean (Vigna radiata [L.] Wilczek) during the growth cycle. Plant Cell Physiol 34: 673-679.

Zhang ZS, Li RQ, Wang JB. (2001) Effect of $\mathrm{Ca}^{2+}$ pretreatment on $\mathrm{Ca}^{2+}$ ATPase activity in the mesophyll cell of pepper seedling under heat stress, Acta Phytophysiol. Sin. 27: 451-454.

Zhang, JH., Liu, YP., Pan, QH., Zhan, JC.,Wang, XQ., Huang, WD. (2006) Changes in membrane-associated $\mathrm{H}+-$-ATPase activities and amounts in young grape plants during the cross adaptation to temperature stresses. Plant Science 170:768-777. 